Eglpt. J. Aquar. Biol, \& Fish., lol. 9, No. I: $15-40$ (2005) ISSN1110-61.31

\title{
BIOLOGICAL ASPECTS OF THE DIGESTIVE SYSTEM OF CAELATURA TERETIUSCULA (BIVALVIA: UNIONIDAE)
}

Mohamed S. Gabri', Abd El-Halim A. Saad ${ }^{2}$, Reda H. Aly ${ }^{2}$ and Abeer A. Fawaz

1 - Zoology Dept., Faculty of Science. Helwan Unir.

2- Zoology Dept.. Faculty of Science. Ain Shams Univ.

key word: digestive system. Caelatura teretiuscula , anatomy . histology

\section{ABSTRACT}

The digestive system of the clam Caelanura teretiuscula consists of the mouth, oesophagus, complicated stomach. combined style sac and mid gut. intestine. rectum and digestive gland.

The combined mid gut and style sac are differentiated into four regions. The crystalline style. is lodged inside the style sac and projected into the lumen of the stomach. There are three groups of digestive gland ducts that open into the stomach.

The microscopic examination of the interior surface of the digestive tract is formed of a single layer of columnar cells provided with cilia. varying in their length and density. These cells have oval nuclei which occupy variable levels. There are some club-shaped secretory cells distributed berween the columnar ones. They acquired deep magenta colour with PAS. The digestive gland tubules are lined with two main cell types: the digestive and secretory cells. Its duct is lined by a layer of ciliated columnar cells.

Histochemically. the digestive cells exhibited a moderate colouration with PAS and mercuric bromophenol blue. However. the secretory ones displayed a dark magenta and blue color with PAS and bromophenol respectively:

\section{INTRODLCTION}

The hivalies play an important role in the food chain and economy of aquatic ecosystem. The shells of bivalues have a high value for producing a fine lime used in pottery glazes and are considered as a source of buttons. On the other hand. the wood toring hivalues cause considerable damage to ships and other Hooden structures in the marine enviromment (Wallace and Taylor. 1997). Some bivalues act as intermediate hosts for sereral 
trematodes such as Anodonfa piscinalis. the intermediate host of the cercaria produced by the trematode Rhipidoconle funnica (Taskinen. 1998).

Freshwater bivalves show great variation in their morpholog: and systematically it is a difficult group (Mandahl- Barth. 1988). The same author mentioned that most african freshwater bivalves belong to two superfamilies. Unionacea and Corbiculacea. The first consists of seven families. among them family Unionidae which is represented by nine genera: Caelatura trestiuscula is the most common species in the River Nile.

The anatomy of the digestive system of certain species of chionine bivalves and Amygdolum species were examined by Jones (1979) and Oliver (2001) respectively. Schneider (1994) found that Nemocardium centifilostum and Clinocardium nuttallii were anatomically similar, but the digestive system of $C$. nuttalii is more complicated than of $N$. centifilosum.

The macroscopic and microscopic anatomy of different clams were studied. Gemma gemma were investigated by Selimer (1967). The anatomy of digestive system of many bivalves have been carried out by Morton (1979). Aboul-Dahab (1983). and Mohamed (1987) studied the digestive system of Modiolus auriculatus and Corbicula species respectively.

The histological investigation of the digestive system of Lyonsia hyalina and Dosinia radiata were studied by Thomas (1993) and Aboul-Dahab et al. (1994) respectively. They recorded that the two species have a combined style sac and mid gut in contrast to the observation of Domaneschi and Narchi (1993) on Sphenia antillensis. Also, the structure of the digestive system was demonstrated by De-Oliveira et al. (2000) and Narchi \& Di-Dario (2002). Kraemer \& Lott (1977) described the microscopic anatomy of the digestive system of Corbicula fluminea.

Other works had focused on the stomach and digestive gland of bivalves. Zaki (1945) pointed that this gland is brown in starved animal, while it is green with feeding. Meawhile, Pohlo (1973) and Morton (1973) described the process of digestion of Tagelus 
californianus and Limnoperna fortunei respectively. Moreover. Purchon (1960. 1987) studied the structure of the stomach of many bivalves and he classified it into 7 types.

The histochemistry of the digestive system of Arctica islandica, and Loripes lucinalis were examined (Palmer, 1979: Johnson el al.. 1996). However. Hily (1985) proved the presence of intracellular enzymatic activities in the lining epithelium of stomach. digestive gland and intestine in $R$. philippinarmm. He stated that the intracellular digestion in the digestive cells occurs by lysosome associated with vacular system.

This work aimed to study the anatomy. histology and histochemistry of the digestive system of Caelanira veruinscula

\section{MATERIAL AND METHODS}

Some samples of the Egyptian clam Caelatura teretiuscula were collected from Shobra El-Mezallat at the connection between the River Nile and Ismailia Canal in Cairn governorate.

These clams are usually found partially or completely embedded in a muddy' bottom. They were collected by scraping the bottom and shoving the net to and fro on the water surface. so that this mud was washed out leaving the specimens. Living $C$. teretiuscula were picked up by forceps and put in a container with some water of the canal. then transported to the lab.

For anatomical studies. the digestive system was dissected out the soft parts and put in $0.5 \%$ saline solution. Drawing was carried out by using a dissecting microscope provided with a camera lucida.

Some of different parts of the digestive system were fixed in Bouin's fluid for 24 hours for histological studies. Other pans were fixed in alcoholic Boun's fluid and $10 \%$ formalin for 24 hours for detecting the general carbohydrates and total proteins respectively: The fixed tissues were dehydrated. cleared and then embedded in wax.Serial sections were cut at $50 \mathrm{~m}$ thickness. the sectioned tissues were deparaffinized. hydrated and stained. The sections which were fixed in aqueous Bouin were stained by haematoxylin and counter 
eosin. The tissues that were fixed in alcoholic Bouin and $10 \%$ formalin were stained by periodic acid Schiff reagent (PAS). and mercuric bromophenol blue respectively. The stained sections were mounted and microscopically examined

\section{A) Anatomical studies (Fig. 1)}

The digestive system of $C$. ieretiuscula consists of:

\section{1- The mouth}

It is a compressed slit-shaped. located dorsally to the foot and posteroventrally to the anterior adductor muscle. It is bounded on either side by two flaps called the outer and inner labial palps. The outer palps of both sides are fused together above the mouth to form the upper lip. while, the two inner ones are united below the mouth to form the lower lip.

\section{2- The oesophagus}

The mouth leads to a dorsoventrally flattened oesophagus. It measures about 0.54 and $0.05 \mathrm{~mm}$ in length and width respectively. The oesophagus passes upwards to open at the anteroventral margin of the stomach.

\section{3- The stomach}

It is a complicated large sac- like structure. located at the anterior part of the visceral mass below the umbo. It measures about 0.56 length and $0.27 \mathrm{~mm}$ width. The stomach is completely covered by the digestive gland.

\section{4- The combined style sac and mid gut}

It measures about $2.7 \mathrm{~mm}$ in length and $0.7 \mathrm{~mm}$ in width. From the posterior floor of the stomach a combined style sac and mid gut pass posteroventrally into the visceral mass, then bend anterodorsally to lead to the intestine. The crystalline style is a transparent rodlike,strueture. Its anterior end is protruded into the stomach. while the posterior one is lodged inside the style sac.

\section{5- The intestine}

It is the longest part of the alimentary tract. It measures about $3.8 \mathrm{~mm}$ in length and $0.5 \mathrm{~mm}$ in width. It passes posterodorsally then bends anteroventrally and turns towards its origin to join the rectum. 


\section{6- The rectum}

It measures about $2.06 \mathrm{~mm}$ and $0.9 \mathrm{~mm}$ in length and width respectively. It runs straight backwards then passes through the pericardium penetrating the ventricle then it passes over the posterior adductor muscle and opens by the anus near the exhalant siphon.

\section{The digestive gland}

It is an irregular mass and its colour varies from green to dark brown, surrounding the stomach completely. The digestive gland consists of a large number of compact tubules.

\section{B) Histological and histochemical studies}

\section{1- The mouth (Figs. 2-7)}

The mouth is bounded on either side by outer and inner labial palps. These palps are united above and below the mouth to give the upper and lower lips (Fig. 2). These lips enclose a short region called preoral vestibule (Fig. 3)

The lining epithelium of the lip is composed of a single layer of ciliated columnar cells with acidophilic finely granulated cytoplasm. Each cell contains an oval basal nucleus. The epithelial cells rest on a basal lamina which is followed by a layer of muscle fibres and connective tissues (Fig. 4).

There are some club- shaped secretory cells that are distributed among the columnar cells. These secretory cells have coarse granules that exhibited a deep colour with haematoxylin and cosin stains (Fig. 4).

Histochemically, the ground cytoplasm of the secretory cells shows a deep magenta colour with PAS, denoting a high carbohydrate content (Fig. 5).

The lining epithelium of the mouth is formed of a single layer of tall ciliated columnar cells. Their cytoplasmic inclusions are acidophilic and granulated. These columnar cells have a darkly stained oval nuclei that occupy variable levels of the cells. These cells rest on a basal lamina followed by a layer of circular muscle fibers and a connective tissue (Fig. 6). 
Some secretory cells are found among the columnar cells. They are club-shaped and contain granulated cytoplasm (Fig. 6).

Histochemically, the secretory cells displayed intensive colouration with PAS, indicating their dense carbohydrate inclusion (Fig. 7)

\section{2- The oesophagus (Fig. 8)}

The microscopic examination shows that the oesophageal lumen is provided with numerous folds. Its wall is lined with a single layer of tall ciliated columnar cells. Their cytoplasm is acidophilic with fine granules and the nuclei are oval and basal.

\section{3- The stomach (Figs. 9-14)}

The oesophagus opens into the stomach through a compressed vestibule on the anterior side (Fig. 9). There is an appendix which projects upward of the stomach roof named as the dorsal hood. This hood is located between the lobes of gastric shield (Figs. 10 \&12). This shield covers the posterior left wall of the stomach and the beginning of the dorsal hood. The function of this shield is to provide a base for grinding the food by rotating head of the crystalline style.

Three groups of wide ducts are emerged from the digestive gland to open into the stomach. At the right side of it, there is a small pocket- like structure called the right caecum. It contains a sorting area and receives a first group of the digestive gland ducts. Another pocket is the left caecum which is found at the left side of the stomach. Its interior surface contains other sorting area and receives a second group of digestive gland ducts (Fig.12). The last pocket appears as a depression known as the left pouch which receives the third group of ducts. On the floor of the stomach, there are two folds, the major and minor typhlosoles, inbetween them the intestinal groove is found (Fig.12).

The microscopic examination of the interior surface of the stomach at the sorting area shows that it has many folds which are lined with ciliated columnar cells, provided with brush border. The 
cytoplasm is positively stained with eosin. Each cell has an oval nucleus lying in a basal position (Fig. 13).

The inner surface of the stomach is covered by ciliated columnar cells with acidophilic cytoplasm. Each cell has an oval nucleus with eccentric nucleolus. The nuclei occupy variable levels in the cells (Fig. 14).

\section{4- The combined style sac and mid gut (Figs. 15-18)}

These two structures are connected by two typhlosoles (Fig. 15). The combined style sac and mid gut are differentiated into four regions; style sac, minor typhlosole, mid gut, and major typhlosole (Fig. 15). These regions are lined with a single layer of ciliated colurinar cells varying in their height and density of cilia according to each region. The lining epithelium rests on a basal lamina followed by a layer of circular muscle fibers and connective tissues (Figs. 16-18).

The style sac epithelium is composed of tall and short ciliated columnar cells. Their cytoplasmic inclusions are acidophilic. These cells have oval nuclei which lie at the basal half of the cells.

The lining of the minor typhlosole epithelium is formed of tall ciliated columnar cells with club- shaped secretory cells inbetween. These secretory cells exhibited dark stain with haematoxylin and eosin preparation (Fig. 16). This region is responsible for the formation of crystalline style and facilitates its rotation by the action of the cilia.

The mid gut is lined by uniformly ciliated columnar cells. These cells contain acidophilic cytoplasm. Each cell has an oval nucleus. The apical parts of these cells are provided with very clear brush border (Fig. 17).

In the major typhlosole. the epithelial cells are tall ciliated columnar and provided with oval basal nuclei with centric nucleoli. The club- shaped secretory cells are darkly stained with haematoxylin and eosin preparation (Fig. 18).

5- The intestine (Figs. $19 \& 20$ ) 
The intestinal wall consists of a single layer of ciliated columnar cells and their ground cytoplasm is distinctly acidophilic. These cells contain oval nuclei and basally situated in their position. Each nucleus has a centric nucleolus (Fig. 19). There are some elongated secretory cells with coarse granules. The cells are densely stained with haematoxylin and eosin (Fig. 19).

Histochemically, these secretory cells give a positive reaction with PAS, denoting their carbohydrate contents (Fig. 20)

6- The rectum (Figs. 21-23)

The microscopic structure of the rectum through the pericardium shows that it is provided with a typhlosole (Fig- 2l). The lining epithelium of this region is composed of a single layer of ciliated columnar cells. Each cell has an oval basal nucleus provided with small eccentric nucleolus. The epithelial cells rest on a basal lamina followed by a layer of muscle fibres. Inside the ventricle. the rectum becomes rounded and the typhlosole disappears. The epithelial cells of the rectum vary from cuboidal to columnar ciliated cells. Their oval nuclei take variable levels and are provided with one or two nucleoli (Fig. 22).

Histochemically, the secretory cells displayed a dark magenta colour with PAS reagent, indicating their carbohydrate contents (Fig. 23)

\section{The digestive gland (Figs. 24-26)}

The digestive gland consists of a great number of digestive tubules which are connected with each other by a connective tissue. Each tubule has a wide irregular lumen (Fig. 24). Few amoebocytes are in close contact with the outer surface of the digestive tubules. The wall of each tubules is lined with two main cell types; digestive and secretory cells (Fig. 24)

\section{Digestive cells}

They are tall columnar cells. Their cytoplasmic contents are acidophilic and granulated. The nucleus is rounded and located at the basal part of the cell. Each cell has a centric nucleolus (Fig. 24). These cells displayed a mild colouration with PAS (Fig. 25) and 
mercuric bromophenol blue (Fig. 26), indicating the low carbohydrate and protein inclusions respectively.

\section{Secretory cells}

These cells are few and pyramidal. Their cytoplasnic inclusions are highly acidophilic. The nuclei are large spherical located at the basal part of the cells and contain central nucleoli (Fig. 24). These cells secrete the digestive enzymes and mucous. they displayed a dark magenta colour with PAS due to the presence of high carbohydrate contents (Fig.25). They exhibited a dark blue with mercuric bromophenol blue, indicating their protein inclusions (Fig. 26).

The digestive gland duct is lined with columnar epithelium that varies in their height provided with cilia. These epithelial cells contain a centrally located, oval-shaped basophilic nucleus (Fig. 27).

\section{DISCUSSION}

The digestive system of $C$. rereriuscula consists of the alimentary tract and the digestive gland. In general. the basic plan of orcanization of the digestive system is more or less similar to that described in Corbicula species (Mohamed. 1987). Lyonsia hyalina (Thomas, 1993) and Dosinia radiata (Aboul- Dahab et al.. 1994). In the present investigation. the food particles pass through the oesophagus into the stomach not only by ciliary action as recorded by Purchon (1977) but also by muscular contraction as in Dosinict radiata (Aboul- Dahab er al.. 1994).

The structure of the stomach in the present study is very complicated like that of other filter feeding bivalves (Purchon. 1987: Dinamani. 1967). Purchon (1960) and Dinamani (1967) observed that. the internal structure of the stomach is very similar in all species of the superfamily Unionacea. Purchon (1987) classified the bivalve stomach into seven types (V'II). He suggested that. the stomach of superfanily Unionacea belongs to type four A (IVA).

The style sac and mid gut of ( . tereliuscula are combined as recorded in Clavagella australis (Morton. 1984): Corbicula species (Mohamed. 1987). Lyonsia hylina (Thomas. 1993). and Amigdolum anoxicolm (Oliver. 2001). However. the two structures are partially. 
combined in Crassostria virginica (Galtsoff. 196t). where there is a narrow slit joining the style sac over its entire length to the mid gut. On the other hand. the former structures are completely separated in Sphenia cantillensis (Domaneschi and Narchi. 1993).

The wall of the combined style sac and mid gut of the present clam is differentiated into four regions (style sac. minor typhlosole. mid gut and major typhlosole). This observation agree with that described by Morton (1983) and Oliver (2001). Meanwhile. Morton (1979) divided it into three regions while Aboul-Dahab et al. (1994) classified the wall of this combined structure into five regions.

In $C$. teresiuscula. the lining epithelium of the style sac is formed of ciliated columnar.cells. Aboul-Dahab et al. (1994) showed that the style sac cells are vacuolated and secrete the crystalline style. while Morton (1983) concluded that these cells are ciliated and its function is to rotate the style. The wall of the mid gut of $C$. leretiuscula is lined by ciliated columnar cells with no secretory cells as described by Judd (1979). The function of these cells is to transport the secretion of the major typhlosole into the style sac (Morton, 1983). In addition, Thomas (1993) found that these cells transport the particles into the intestine.

In the present study, the rout of the rectum as in most bivalves passes through the ventricle as in Pandora inaequivalvia and Cleidothaerus species (Morton, 1974). However, in Clavergella australis (Morton, 1984) the rectum passes through the ventricle and kidney.

Generally, the lining epithelium of the alimentary tract in the present study is composed of ciliated columnar cells varying in their length according to each organ as in Corbicula species (Mohamed. 1987), Lyonsia hyalina (Thomas, 1993) and Dosinia radiata (AboulDahab et al., 1994).

The structure of the digestive gland and their ducts in $C$. teretiuscula is basically similar to that of many other eulamellibranchs that where described by Mohamed (1987) and Aboul-Dahab et al. (1994) . 


\section{REFERENCES}

Aboul-Dahab. H. M. (1983). Morphological studies on a marine bivalve species in Egypt .Hodiolas anriculanas (Kraus. 18+\$). M. Sc. Thesis. Assiut Unir.. Cairo. A.R.E.

Aboul-Dahab, H.M.: El-Helw. M.R.: Yassen. A.E. and Amine. G.S. (1994). The digestive system of Dosinia ractiala (Mollusca: Bivalvia) collected from the Red Sea. Egypt. Assiut. Vit. Med. J., 31: 56-86.

De-Oliveira - Castro - Gueron. C. and Narchi. W. (2000). Functional anatomy of Prorothaca (Leukoma) pectorines (Lamark) (Bivalvia: Veneridae). Rev. Bras. Zool.. 17 (4): $1007-1039$.

Dinamani, P. (1967). Variation in the stomach structure of the Bivalvia. Malacologia. 5 (2): 225-268.

Domaneschi, O. and Narchi. W. (1993). The functional anatomy of Sphenia antillensis (Dall \& Simpson. 1901) (Bivalvia: Myidae). J. Moll. Stud., 59: 195-210.

Galtsoff, P. S. (1964). "The American oyster Crassosirea virginicci" (Gmelin) Fishery Bulletin of the Fish and Wild life Service.vol. 64 .

Hily, A. C. (1985). Histoenzymological study of digestion of Ruditapes Philippinarrum. Bioloical Basis in Aquaculture Montepellier.12-16 December-1983. Basis Biologiques - De. L-Aquaculture. Montepellier. 12-16 December-1983Amanieu, M., Laubier, L.; Guille, A. eds. IFREMER, ParisFrance; Pirocean . Paris France 1985, no. 1 pp. $97-108$.

Johnson, M. A.; Paulet, Y.M.; Donval. A. and Le-Pennec, M. (1996). Histology. histochemistry and enzyme biochemistry in the 
digestive system of the endosymbiont - bearing bivalve Loripes lucinalis (Lamarck). J. Exp. Mar. Biol. Ecol.. 197 (1): $15-38$.

Jones. C. C. (1979). Anatomy of Chion cancellata and some other chionines (Bivalvia: Veneridae). Malacologia. 19 ( [): 157-199.

Judd. W. (1979): The secretion and fine structure of bivalve style sac. Ophelia. 18: 205-233.

Kraemer. L. R. and Lott, S. (1977). Microscopic anatomy of the visceral mass of Corbicula fluminea (Bivalvia: Sphaeracea). Bull. Amer. Malacol. Union. +3: 48-56.

Mandahl. Barth, G. (1988). "Studies on African freshwater bivalves" Danish Bilharziasis lahoratory. Jaegerborg Alle IDDK 2920 Charlottenlund. Denmark.

Mohamed. T. A. E (1987). Studies on freshwater Eulamellibranches Cimbicula clams. M.Sc. Thesis. Assiut Univ.. Cairo. A.R.E.

Alorton. B. (1973). Some aspects of the biology and functional morphology of the organs of feeding and digestion of Limmoperna fortunei (Dunker) (Bivalvia: Mytilacea). Malacol. 12: $265-281$.

Morton. B. (1974). Some aspects of the biology and functional morphology of Cleidothaerus maorianus (Bivalvia: Anomalodesmata). Proc. malac. Soc. Land.. 41: 201 -222.

Miorton. B. (1979). The biology. functional morphology and taxonomic status of Gaimardia Acogamardia) Linloyi (Bivalvia: Gaimardidae).. I. Zool. London. 188:123-1 2 .

Morton. B. (1983). Feeding and digestion in the bivalvia. in the Mallusca.5: Physioldgy part 2 (A. S. M. Saleuddin \& K. M. Walbur eds). $139-224$ Academic press. New York.

Mforton. B. (1984). The biology and functional morphology of (Yorugclla unstrulis (Bivalvia: Anomalodesmala). T. Zool. ?(1): +89-511. 
Narchi. W and di-Dario. F. (2002). The anatomy and functional morphology of Tivela ientricoses (Gray: 1838) (Bivalvia: Veneridae). Nautilus. $1 / 6(1): 13-24$.

Oliver. P.G. (2001). Functional morphology and description of new species of Amygdolum (Mytiloidea) from the oxygen minimum zone of Arabian Sea .J. Moll. Stud.. 6-: 255 - 241.

Palmer, R. E. (1979). A histological and histochemical study of digestion in the bivalve Arcticu islandica - L. Biol. Bull. Mar. Biol. Lab. Woods - Hole, $156(1): 155-129$.

Pohlo. R. H. (1973). Feeding and associated functional morphology in Tagelus californianus and Florimatis obesa (Bivalvia: Tellinacea). Malacol, 12 (1):1-11.

Purchon, R. D. (1960). The stomach in the Eulamellibranchia: stomach Type IV and V. Proc. Zool. Soc. Lond.. 135:431-489.

Purchon. R. D. (1977). "The biology of the Mollusca" Vol. 57. pergamon press: Oxford. New York. Torento. Sydney. Paris.

Purchon, R. D. (1987). The stomach in the bivalvia. Philosophical Trans. Roy. Soc. Lond. B., 316: 183-276.

Schneider, J. A. (1994). On the anatomy of the alimentary tract of the bivalves Nemocardium (Keenaea) centifilosum (Carpenter, 1864) and Clinocardium nuttallii (Cardiidae). Veliger, 37(1): 36-42.

Sellmer, G. P. (1967). Functional morphology and ecological life history of the gem clam Gemma gemma (Eulamellibranchia: Veneridae). Malacol, 5 (2):137-223.

Taskinen, J. (1998). Cercarial production of trematode Rhipidocotyle fennica in clams kept in the field. J. Parasitol., $8+(2): 345$ 349. 
Thomas. K. A. (1993). The functional morphology of the digestive system of Lyonsia hyalina (Conrad, 1831) (Bivalvia: Anomalodesmata: Pandoroidea). J. Moll. Stud., 59: 175-186.

Zaki. F. G. (1945). Some morphological and physiological aspects of the digestive diverticula of Unio praesidens, Bourg. M. Sc. Thesis. Fouad 1 st. Lniv. Cairo. A.R.E.

\section{EXPLANATION OF FIGURES}

Fig. 1: Diagramatic drawing of the digestive system after partial removal of digestive gland and gonad, showing anus (a). anterior adductor muscle (aam). auricle (au), digestive gland (dg). exhalant siphon (ex), foot (f). gonad (g). inhalant siphon (in). iniestine (I), labial palps (lps), mouth (mo), oesophagus (oe), posterior adductor muscle (pam), pericardium (pe), rectum ( $\mathrm{r}$ ). right mantle lobe ( $\mathrm{rml})$, stomach $(\mathrm{s})$. combined style sac and mid gut (ss\&mg) and ventricle (ve).

Fin.?: Photomicograph of T.S. Lhrough the labial palps sinwing the inner (ilp) and outer (olp) labial palps. (Bouin-Hx\&E) 40X.

Fig.3: Photomicrograph of L.S. through the anterior region of the digestive system. showing lower lip (li). mouth (mo). ocsophagus (oe). preoral vestibule (ov) and upper lip (ul). (Bouin-Hx \&E) 100X:

Fig.4: Photomicrograph of enlarged portion of L.S. of the lower lip. showing ciliated columnar epithelium (cc). secretory cells (se). muscle fibres (arrows) and connective tissue (ct). (Bouin-Hx \& E) 400X.

Fig. 5: Photomicrograph of enlarged portion of L.S. of the lower lip showing positive reaction of secretory cells (se). for general carbohydrates (Alcoholic Bouin-PAS and counter stain haematoxyline. $H x)+00 x^{\circ}$.

Fig.6: Photonicrograph of enlarged portion of T.S. of the mouth showing ciliated columnar epithelium (cc). secretony cells (sc) and connective tissue (ct). (Bouin- $\mathrm{Hx} \& \mathrm{E}$ ) 400X.

Fig. 7: Photomicrograph of enlarged portion of T.S. of the mouth showing positive reaction of secretory cells (sc). for general carbohydrates. (Alcoholic Bouin-P.AS) 400X. 
Fig. 8: Photomicrograph of T.S. of the oesophagus showing numerous folds (Bouin- Hx \& E) $40 X$.

Fig. 9: Photomicreograph of L.S. of digestive system showing digestive gland ( $\mathrm{dg}$ ) oesophagus (oe), stomach (s), combined style sac and midgut (ss\&mg) and vestibule (v). (Bouin- $\mathrm{Hx}$ \& E) $40 X$.

Fig. 10: Photomicrograph of L.S. of the stomach showing the dorsal hood (dh) and two lobes of gastric shield (gs). (Bouin-Hx \&E) $40 \mathrm{X}$.

Fig. 11: Photomicrograph of the enlarged portion of L. S. of stomach showing ciliated columnar epithelium (cc). (Bouin-Hx \&E) $100 X$.

Fig. 12: Photomicrograph of T.S. of the stomach showing: digestive gland duct (dd), digestive tubule (tu), dorsal hood (dh), gastric shield (gs), left caecum (lc), left pouch (Ip), minor typhlosole (mty), major typhlosole (mjty) right caecum (rc) and intestinal groove (arrow) (Bouin-Hx \& E) 40X.

Fig. 13: Photomicrograph of enlarged portion of T.S. of the sorting area showing many folds lined with ciliated columnar epithelium (cc) (Bouin- Hx \& E) 400X.

Fig. 14: Photomicrograph of enlarged portion of T.S. of the stomach showing ciliated columnar epithelium (cc) (Bouin-Hx \& E) $400 X$.

Fig. 15: Photomicrograph of T.S. of the combined style sac and mid gut showing connective tissue (ct), circular muscle fibres (arrow), style sac (ss), minor typhlosole (mty) mid gut (mg), major typhlosole (mjty) and crystalline style (cs).(Bouin-Hx \& E) $100 \mathrm{X}$.

Fig. 16: Photomicrograph of enlarged portion of T.S. of the minor typhlosole showing ciliated columnar epithelium (cc), secretory cells (ce) and crystalline style (cs) (Bouin-Hx \& E) $400 \mathrm{X}$.

Fig. 17: Photomicrograph of enlarged portion of T.S. of the mid gut showing ciliated columnar epithelium (cc), circular muscle fibres (arrow), connective tissue (ct) and crystalline style (cs). (Bouin-Hx \& E) 400X. 
Fig. 18: Photomicrograph of enlarged portion of T.S. of the major typhlosole showing ciliated columnar epithelium (cc), secretory cells (se) and crystalline style (cs).(Bouin-Hx \& E) $400 \mathrm{X}$.

Fig. 19: Photomicrograph of enlarged portion of T.S. of the intestine showing ciliated columnar epithelium (cc), secretory cells (se), circular muscle fibres (arrow) and connective tissue (ct). (Bouin- Hx \& E) 400X.

Fig. 20: Photomicrograph of enlarged portion of T.S. of the intestine showing positive reaction of secretory cells (se) for general carbohydrates. (Alcoholic Bouin-PAS) 300X.

Fig.21: Photomicrograph of $T$. S. of the rectum (r) inside the pericardium (pe) showing circular muscie fibres (arrow) and typhlosole (ty). (Bouin-Hx \& E) 100X.

Fig. 22: Photomicrograph of $T$. S. of the rectum (r) inside the ventricle showing ciliated columnar epithelium (cc) and secretory cells (arrows). (Bouin-Hx \& E) 400X.

Fig. 23 Photomicrograph of enlarged portion of T.S. of the rectum inside the ventricle showing strong reaction of secretory cells (se) for general carbohydrates. (Alcoholic Bouin-PAS) 400X.

Fig. 24: Photomicrograph of T.S. of the digestive gland showing: digestive cells (di), secretory cells (se), amoebocytes (arrow) and connective tissue (ct). (Bouin-Hx \& E) 400X.

Fig. 25: Photomicrograph of T.S. of the digestive gland showing: strong reaction of secretory cells (se) for general carbohydrates and weak reaction of digestive cells (di). (Alcoholic Bouin-PAS) 400X.

Fig. 26: Photomicrograph of T.S. of the digestive gland showing: strong reaction of secretory cells (se) for total proteins and: moderate reaction of digestive cells (di). (10\% FormalinBromophenol blue) 400X.

Fig. 27: Photomicrograph of T.S. of the digestive gland duct showing simple columnar epithelial cell (c). (Boun's - Hx \&E.) $400 \mathrm{X}$ 


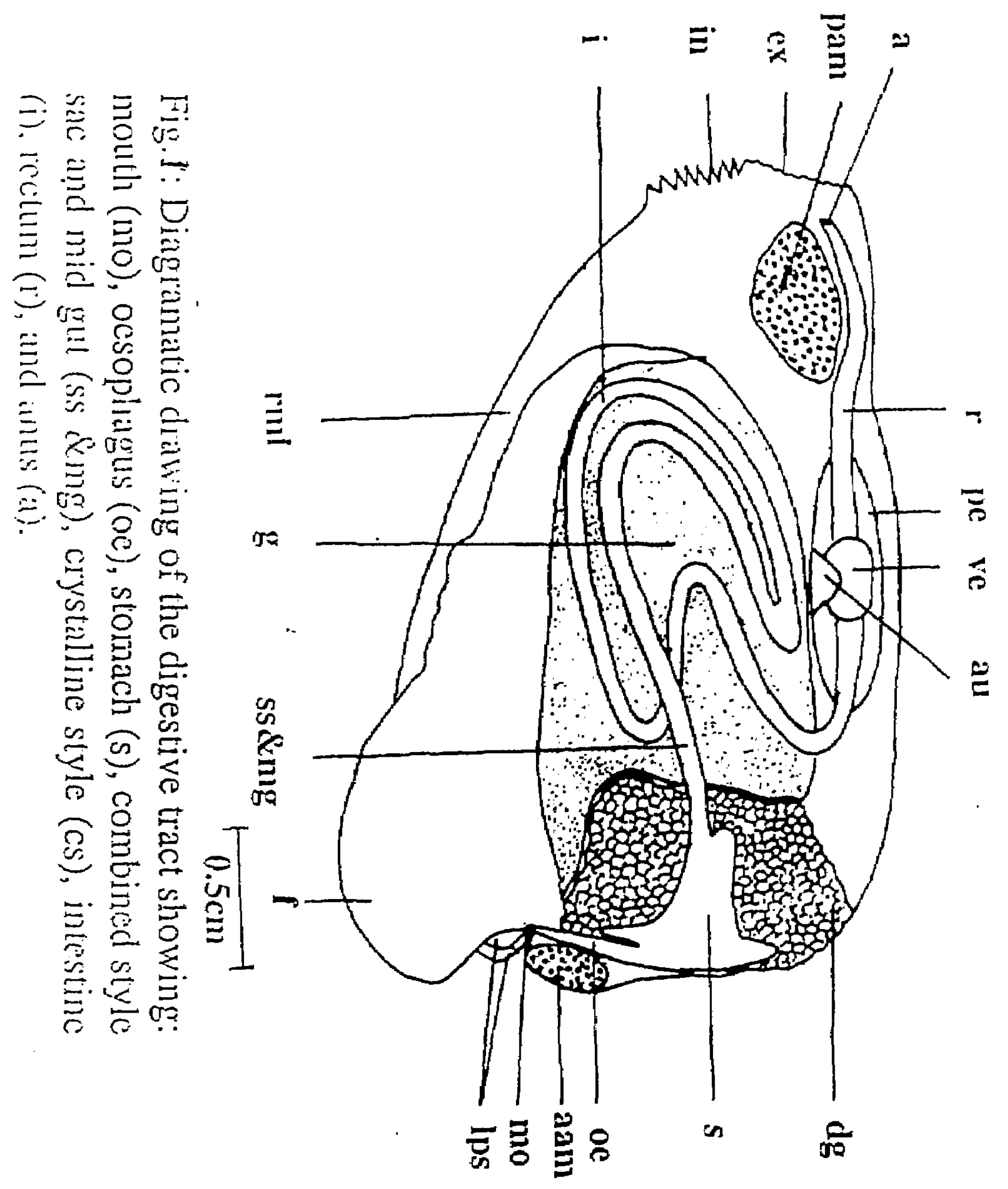



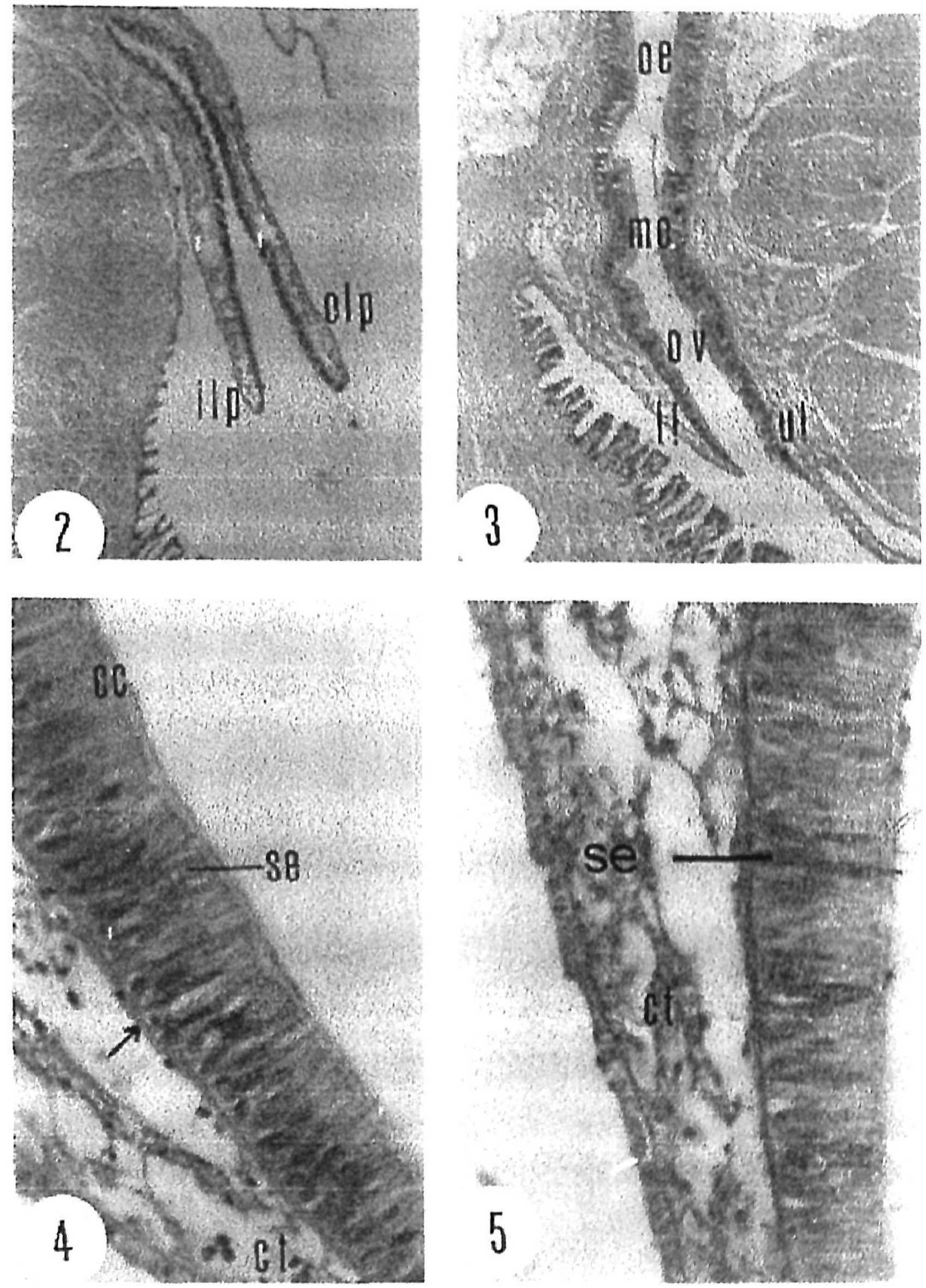

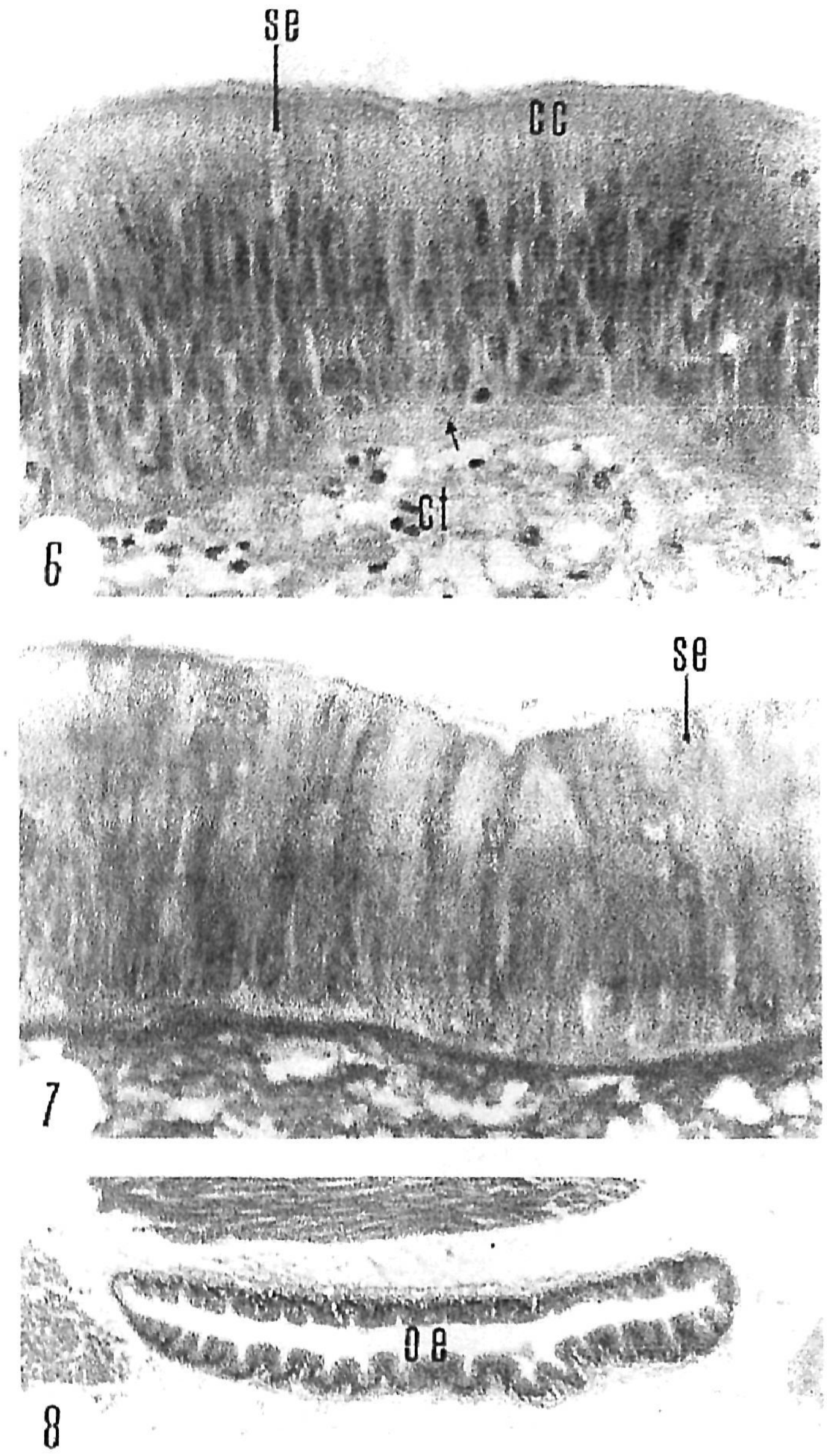

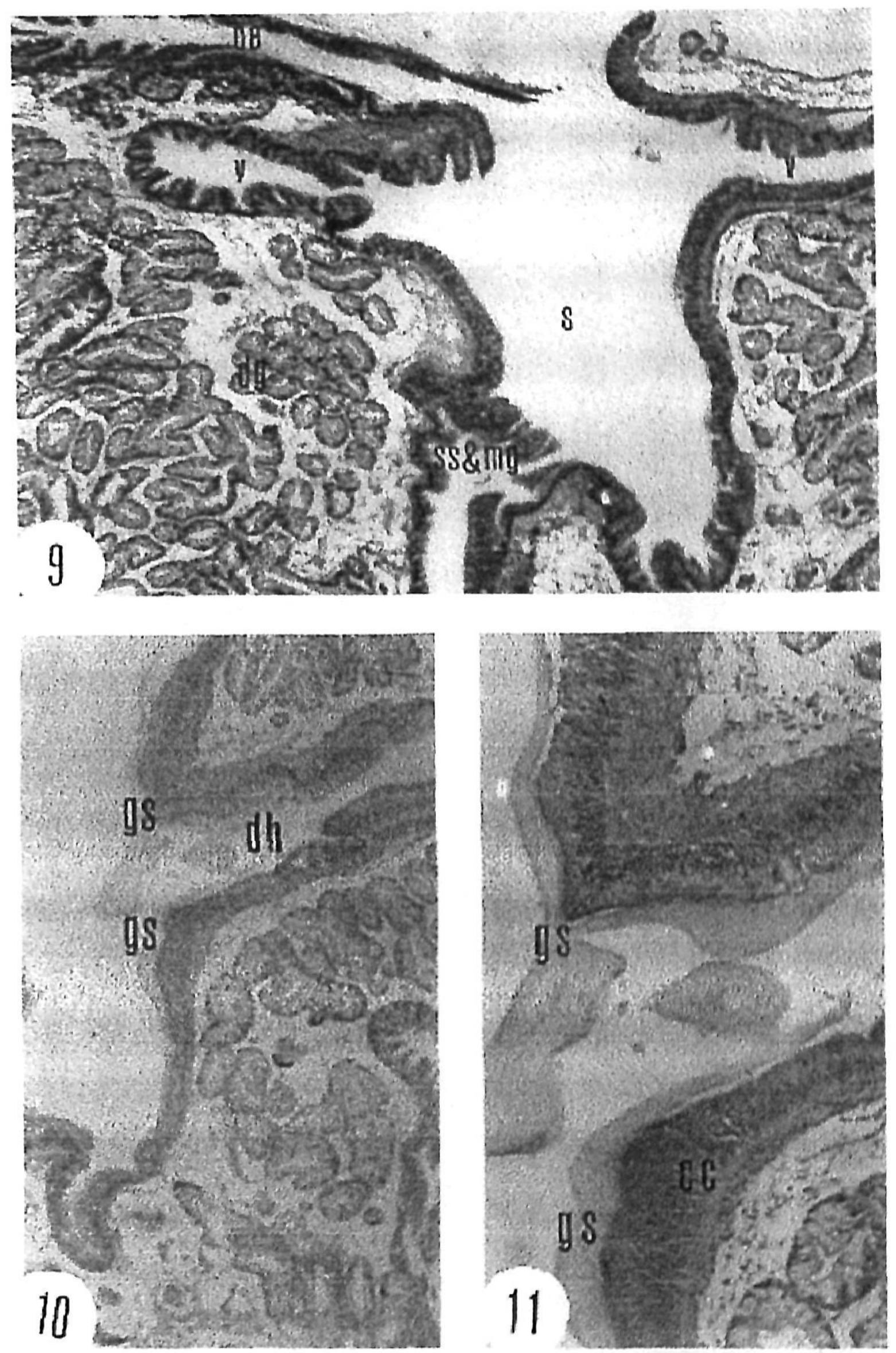

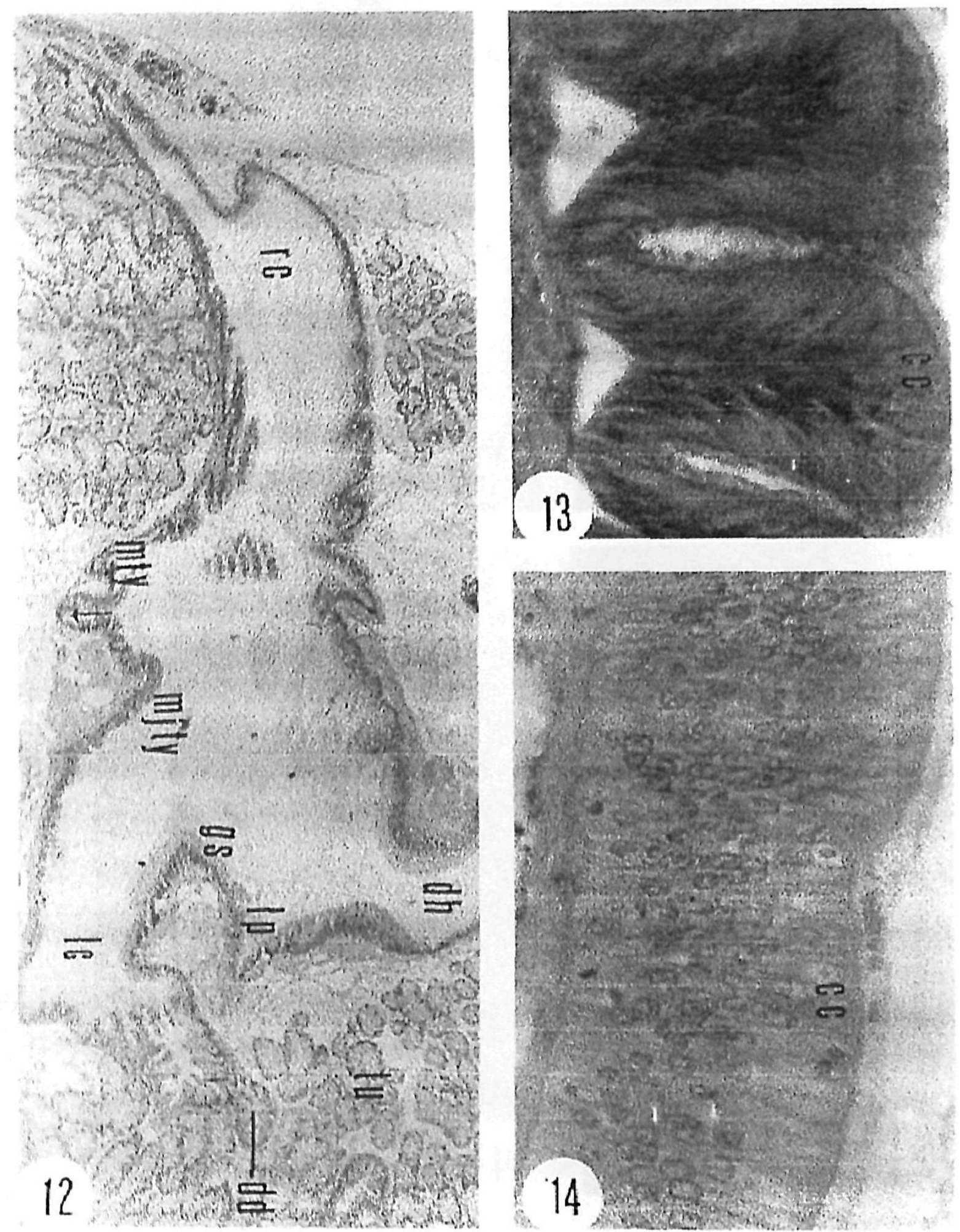

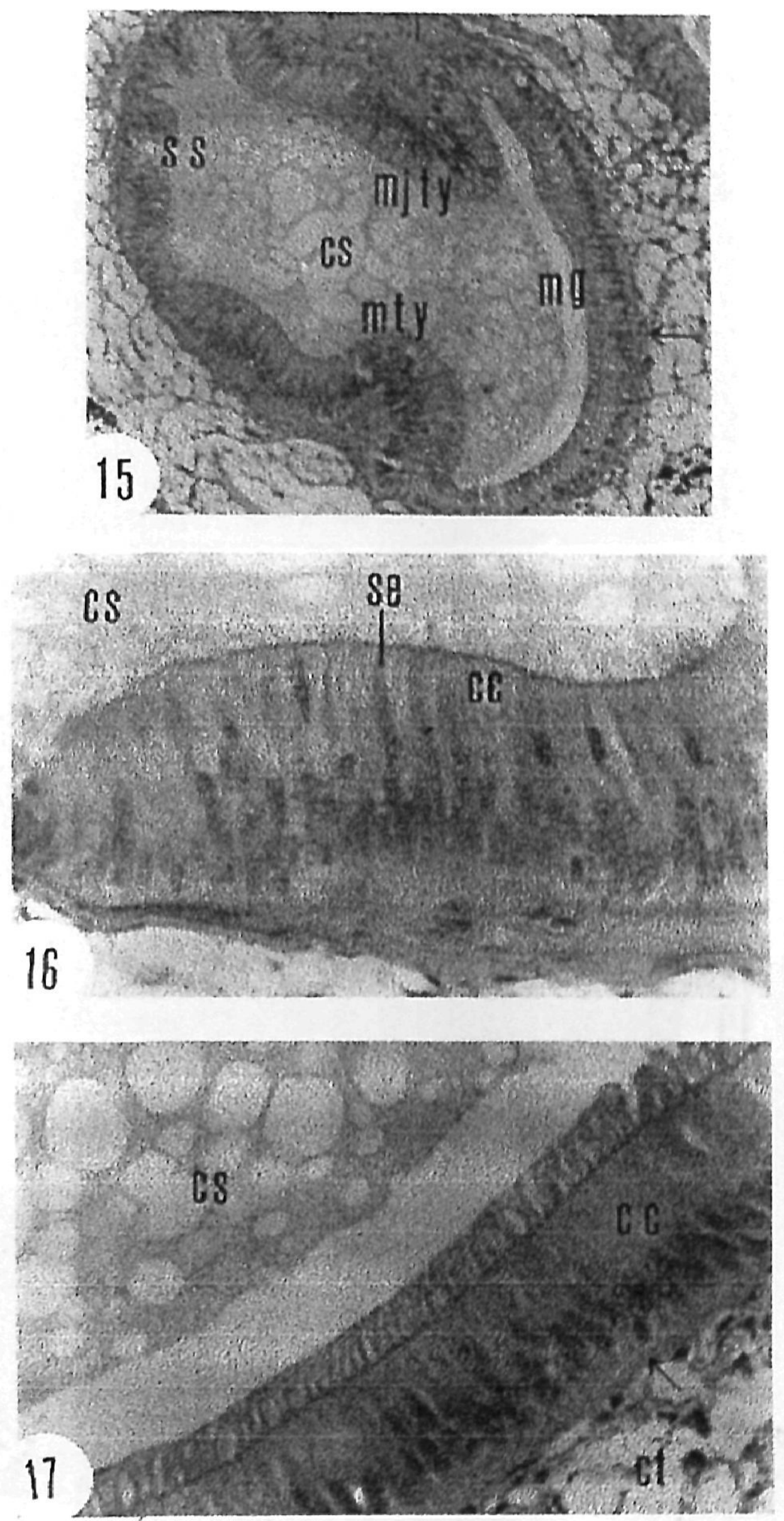



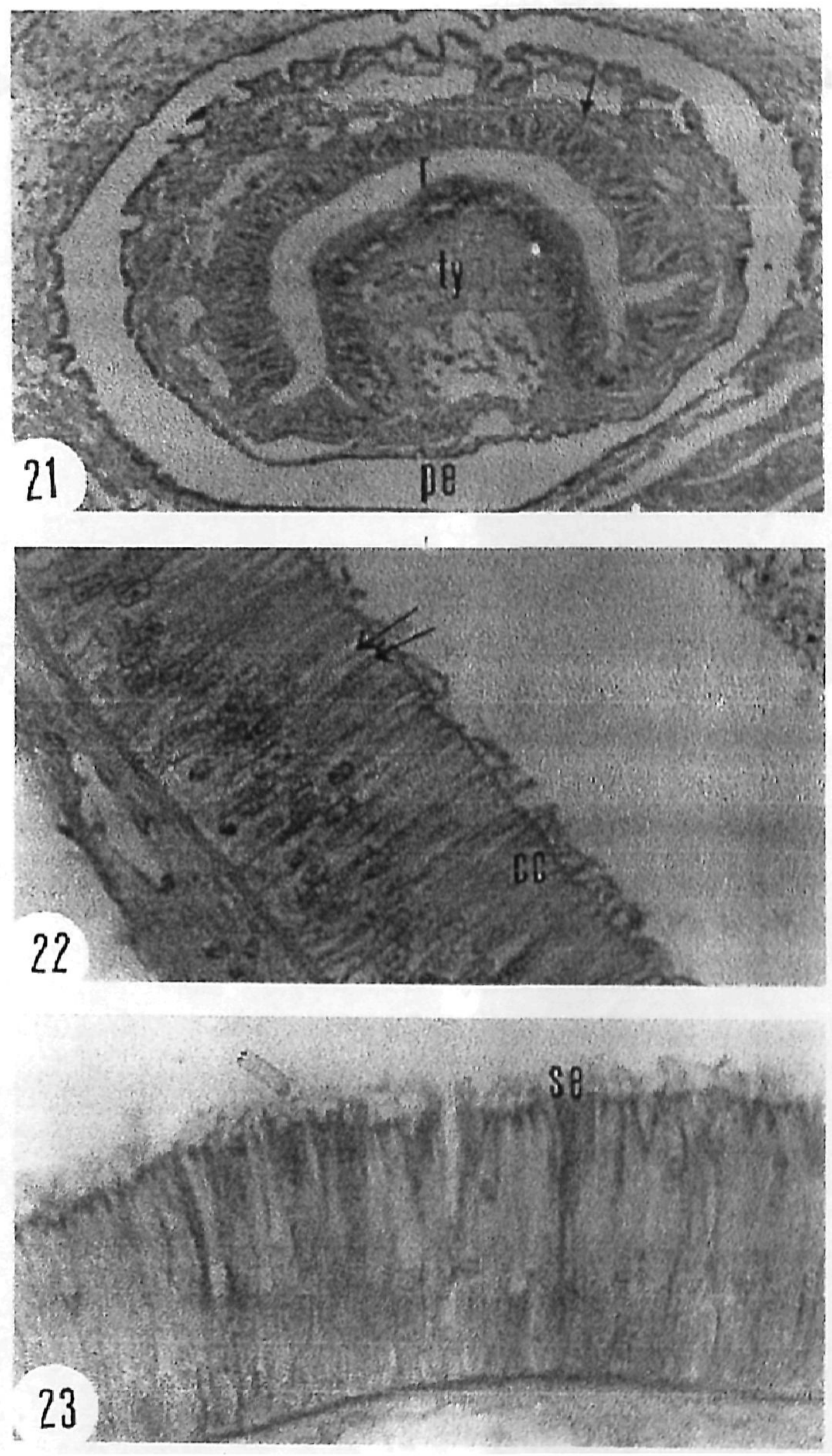

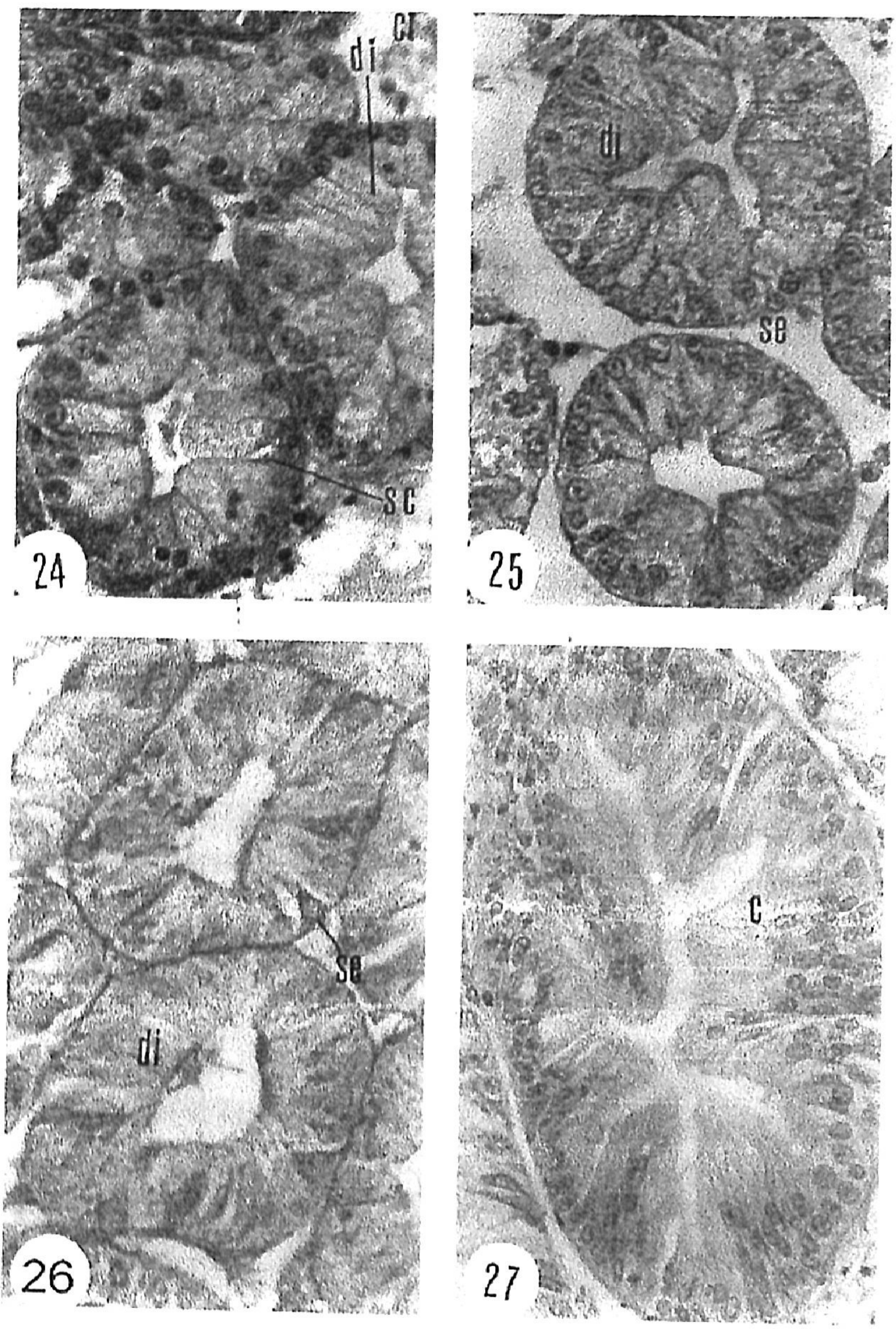